\title{
Removal of natural populations of marine plankton by a large-scale ballast water treatment system
}

\author{
T. D. Waite ${ }^{1, *}$, J. Kazumi ${ }^{1}$, P. V. Z. Lane ${ }^{2}$, L. L. Farmer ${ }^{3}$, S. G. Smith ${ }^{2}$, \\ S. L. Smith ${ }^{2}$, G. Hitchcock ${ }^{2}$, T. R. Capo ${ }^{2}$ \\ ${ }^{1}$ College of Engineering, University of Miami, 1251 Memorial Drive, Coral Gables, Florida 33146, USA \\ ${ }^{2}$ Rosenstiel School of Marine and Atmospheric Science, University of Miami, 4600 Rickenbacker Causeway, Miami, \\ Florida 33149, USA \\ ${ }^{3}$ College of Arts and Sciences, University of Miami, 1301 Memorial Drive, Coral Gables, Florida 33146, USA
}

\begin{abstract}
Large-scale experiments using a hydrocyclone, a self-cleaning $50 \mu \mathrm{m}$ screen, and a UV unit were undertaken to evaluate the treatment efficiency of these commercially available units for preventing the transfer of unwanted species via ships' ballast water. The water flow through the treatment system was approximately $5.7 \mathrm{~m}^{3} \mathrm{~min}^{-1}$. The effect of increased suspended solids on these processes was the focus of this research. During each experimental run, $760 \mathrm{l}$ samples were obtained and passed through $35 \mu \mathrm{m}$ plankton nets for zooplankton collection. Samples were also collected for phytoplankton, microbiological, ATP and protein analyses. After the initial samples were obtained, a second set of samples was held for $18 \mathrm{~h}$ to determine the effects of storage on the effectiveness of treatment processes. Screening the seawater at $50 \mu \mathrm{m}$ removed most of the zooplankton and a small percentage of the microphytoplankton, but hydrocyclonic separation was not effective. Initially, UV treatment reduced the viable count of microorganisms to an undetectable level; however, bacterial regrowth was observed in the samples held for $18 \mathrm{~h}$. Statistical evaluation showed that increased turbidity ( 5 to 90 nephelometer turbidity units; NTU) had no effect on the treatment regime, even on the UV unit. At the highest turbidity ( $90 \mathrm{NTU}$ ), the UV dose was lowered to approximately $35 \mathrm{~mW} \mathrm{~s} \mathrm{~cm}^{-2}$; however, this dose was still sufficient to inactivate microorganisms. Overall, it was observed that only the $50 \mu \mathrm{m}$ screen was effective in the removal of organisms, especially potential invading organisms such as large zooplankton or invertebrate larvae.
\end{abstract}

KEY WORDS: Ballast water treatment - Hydrocyclone - Self-cleaning screen - UV treatment . Plankton Resale or republication not permitted without written consent of the publisher

\section{INTRODUCTION}

It is now accepted that the transport of unwanted organisms due to ships' ballasting procedures has jeopardized many of the earth's natural ecosystems. Successful invasions have been well documented, including the European zebra mussel in the US Great Lakes, Japanese dinoflagellates in Australia, and the North American comb jellyfish in the Black Sea (Hallegraeff 1993, Nalepa \& Schloesser 1993, Ascherson 1996). Mills et al. (1993) noted that over 140 species have been introduced to the Great Lakes of North America alone. More recent data show that the rate of reported invasions has increased rapidly over the past
$200 \mathrm{yr}$, and that most reported invasive species are members of the Crustacea and Mollusca. It has also been noted that in the US, more invasive species are present along the Pacific Coast than along the Atlantic and Gulf Coasts (Ruiz et al. 2000a). There has also been some indication that microorganisms (pathogenic bacteria) may be spread due to ships' ballasting operations. For example Ruiz et al. (2000b) have measured Vibrio cholerae in planktonic samples collected from ships. Microorganisms associated with marine diseases may also be transported via ballast, and Harvell et al. (2000) have documented several new marine diseases affecting corals and marine mammals. They report, however, that where documented, these diseases have 
emerged due to range shifts of hosts, rather than introductions of new pathogens.

Management practices to prevent the transport of unwanted species of ballast water discharges have been slow in evolving. International organizations such as the International Maritime Organization (IMO), through its Marine Environment Protection Committee (MEPC), are working to draft a legal instrument to control ballast water discharges. However, it does not appear that such an instrument will be approved by the IMO before the year 2005. In the meantime, individual port states have initiated their own ballast-water management plans in an attempt to protect their natural resources. The leader in this effort has been Australia, which has initiated ballast-water management scenarios since the early 1990s (AQIS 1994, 1995).

Most recommended and/or required ballast water management scenarios around the world involve the exchange or dilution of in-shore ballast waters with offshore open ocean waters. It is assumed that open ocean waters are greatly reduced with respect to biomass, or the organisms present pose little threat for invasion to in-shore communities. Without dilution or ballast exchange, it has been shown that organisms collected as in-shore ballast water can survive long ocean voyages. In a recent experiment, Gollasch et al. (2000) noted that several planktonic species survived a $23 \mathrm{~d}$ voyage from Singapore to Bremerhaven in Germany. It was also noted that harpacticoid copepods (e.g. Tisbe graciloides) actually increased in abundance by a factor of 100 during the voyage.

While ballast exchange or dilution of in-shore ballast water may be an effective means of controlling the transport of unwanted species, it does pose a significant safety hazard to ships. In a recent study, the American Bureau of Shipping (1999) concluded that because of the complexity of exchange sequences on many vessels, there were significant safety concerns associated with ship stability during empty/refill ballast exchange. They also noted that ballast exchange considerations should be included in the design of new ships to minimize safety issues. Ballast may also be exchanged via continuous dilution while a ship is underway, although in these cases it has been noted that sediments often cannot be diluted as efficiently as the water, especially in those ships that have short transit times (Hay \& Tanis 1998). However, it has been demonstrated that if water is well mixed in the ballast tank, the water can be effectively diluted by continuous pumping (AQIS 1993).

It was concluded early on (National Research Council 1996) that the most effective means of controlling transport of unwanted species due to ships' ballasting procedures would be by inclusion of ship-board treatment systems. They noted that ship-board treatment could be facilitated via ballast water exchange, physical separation of organisms by filtration, or organism inactivation by biocide application. The NRC Committee evaluated the potential efficacy of each treatment approach and ranked the treatment processes according to potential success. According to this evaluation, filtration processes appeared to have the greatest potential for success in preventing transport of unwanted species.

Since the publication of the NRC evaluation, several laboratory and pilot scale experiments have been undertaken to evaluate different treatment systems for minimizing the impact of ballast water transport of unwanted species. Filtration, utilizing self-cleaning screens, was evaluated in the Great Lakes using variable-size opening screens ( 25 to $100 \mu \mathrm{m}$ ), and operational constraints of this system due to excessive pressure drops across the screens were noted (Parsons \& Harkins 2000). Sutherland et al. (2001) reported on the treatment efficiency of a 2-stage ballast water treatment system integrating hydrocyclone and UV treatment. These researchers evaluated the effect of this combined treatment scheme on selected components of the plankton. While the results were somewhat variable, it did appear that the phytoplankton component was affected by the UV treatment, with subsequent reduction in growth potential.

Other treatment approaches have been explored at laboratory- or small-scale. Specifically, the addition of hydrogen peroxide as an aquatic biocide has been tested (Kuzirian et al. 2001), as well as the effect of ballast water de-oxygenation (Tamburri et al. 2002). In all these experiments, different parameters of treatment efficiency were monitored; therefore, it is difficult to compare the various treatment options. In addition to evaluating treatment efficacy of ballast-water treatment options, an attempt has also been made to compare the cost of such treatment systems. Rigby \& Taylor (2001) have estimated costs for treatment systems including filtration, heating, and chemical treatment, as compared to ballast exchange. In all cases, they estimate that ship-board treatment will be at least 10-times more expensive than ballast exchange, and could be significantly higher. It is clear that evaluation of the different treatment options, as well as cost, is dependent on the establishment of treatment standards. Until treatment goals or standards are established by either port states or international agencies, no meaningful comparisons of treatment systems can be made.

Due to the lack of reliable ballast-treatment efficiency data from common unit processes, a large-scale investigation of water treatment systems was undertaken. A dockside test platform operating at $5.7 \mathrm{~m}^{3}$ $\min ^{-1}$ (1500 gpm) was fabricated on Biscayne Bay, 
Miami, Florida, USA, and commercially available treatment systems were installed, including a hydrocyclone, self-cleaning screen (50 $\mu \mathrm{m}$ opening), and a UV treatment system. The effects of the individual primary treatment processes, as well as the overall treatment system, were monitored by evaluating a broad spectrum of biological and biochemical activity. In addition, the suspended solids content (turbidity) of the ambient seawater was augmented by the addition of clay materials in order to test the treatment capability of the unit processes under demanding conditions. The intent was to mimic severe turbid conditions that might be encountered by ballast-water treatment equipment. It was assumed that the increased suspended solids content, and therefore the reduced clarity of the seawater, would most affect the UV treatment process.

\section{MATERIALS AND METHODS}

Description of the ballast water treatment test facility. A schematic diagram of the test facility, including pump, injection pump for clay addition, primary treatment units (hydrocyclone or $50 \mu \mathrm{m}$ screen) and secondary UV treatment device, together with the appropriate catchment reservoirs and sample ports is shown in Fig. 1. The facility included a dockside pump (Marlow Pumps, Model 6E4PEL, self priming), a hydrocy- clone (Krebs Engineers, Model KSH-20-1437), a self cleaning screen (Hayward Industries, Model 596, 325 mesh, $50 \mu \mathrm{m}$ stainless steel element), and a UV system (WEDECO-Ideal Horizons, Model 1H-60 L). The hydrocyclone had a centrifugal force of approximately $13 \times g$ at $5.7 \mathrm{~m}^{3} \mathrm{~min}^{-1}(1500 \mathrm{gpm})$. The UV system was comprised of 60 low-pressure UV-C germicidal lamps (wavelength $254 \mathrm{~nm}$ ) arranged in an array of concentric circles within a stainless steel housing. UV dose was monitored by a sensor probe located on the chamber wall at the point of greatest water depth away from the UV lamps. Signal from the sensor was displayed as a relative percentage reading from 0 to $100 \%$ on the control panel, and the initial UV output at $100 \%$ was determined to be $60 \mathrm{~mW} \mathrm{~s} \mathrm{~cm}^{-2}\left(60 \mathrm{~mJ} \mathrm{~cm}^{-2}\right)$ by the manufacturer. The UV lamps have an operational life of $9000 \mathrm{~h}$, by which point they have lost approximately $40 \%$ of the initial UV output. Over the course of this study, the UV lamps were in operation for less than $20 \mathrm{~h}$. The kaolinite/water slurry used in some of the experimental runs was mixed in a 130 l (35 gal) polypropylene tank and injected into a PVC in-line mixer (Cole Parmer Company) as required. The water was collected in 7601 (200 gal) polypropylene holding tanks (Cole Parmer).

Water for the experimental runs was pumped from Bear Cut (Biscayne Bay, Miami, Florida, USA). The dock at Rosenstiel School of Marine and Atmospheric

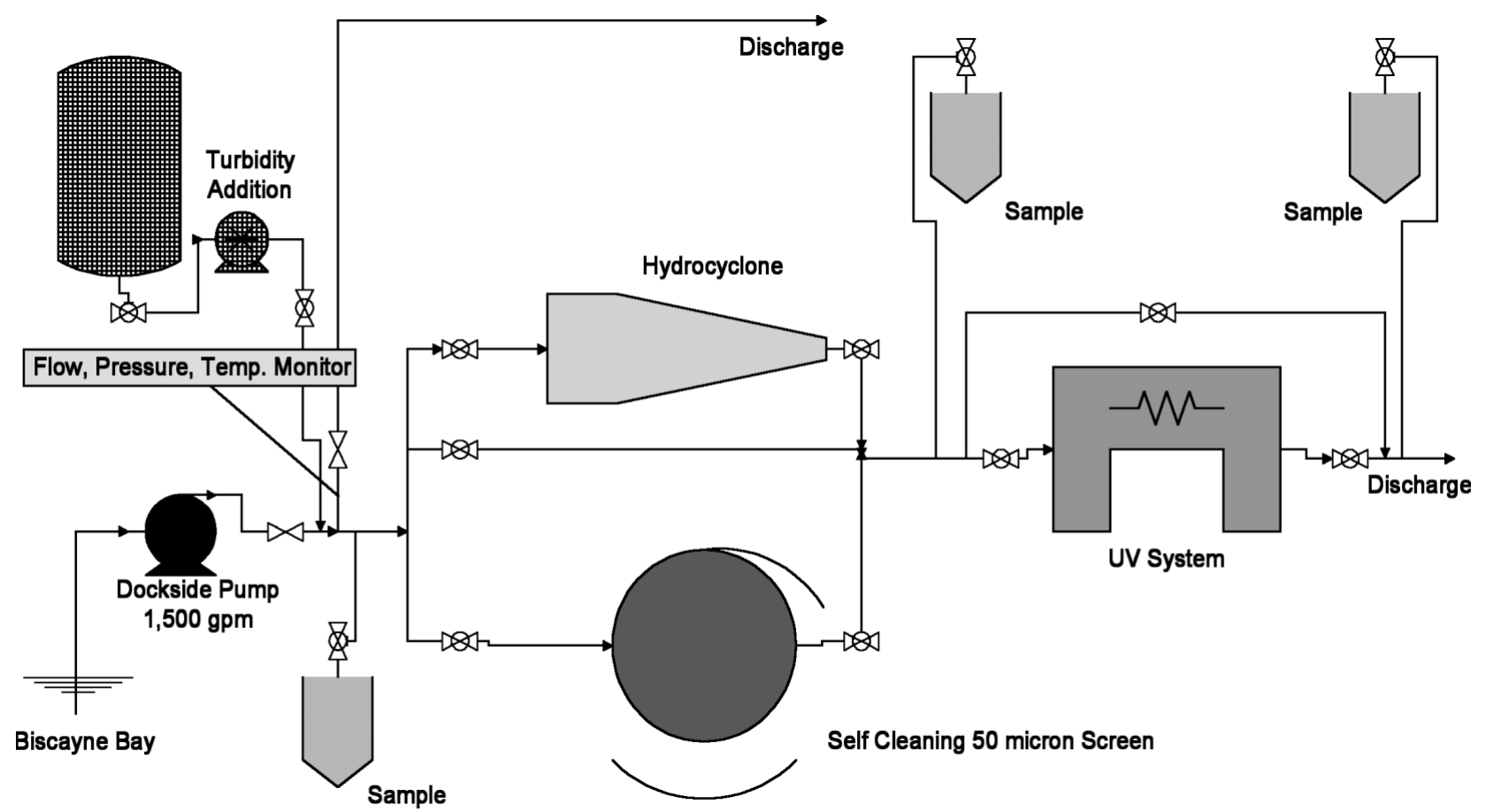

Fig. 1. Schematic diagram of Ballast Water Test Treatment Facility. The facility included a dockside pump, a hydrocyclone, a self cleaning screen, and a UV system. The kaolinite/water slurry used in some of the experimental runs was mixed in a polypropylene tank and injected into a PVC in-line mixer as required. The water was collected in 7601 (200 gal) polypropylene holding tanks. $1500 \mathrm{gpm}=5.7 \mathrm{~m}^{3} \mathrm{~min}^{-1}$ 
Science at the University of Miami is located on Bear Cut, and the filtration and UV treatment devices were built on an area adjacent to the dock. The water in Biscayne Bay typically has a salinity of $32 \mathrm{ppt}$ (range: 28 to $36 \mathrm{ppt}$ ), and temperatures of 18 to $28^{\circ} \mathrm{C}$. The inlet for the pump was at a depth of $3 \mathrm{~m}$ below sea surface, and water flow through the test facility was approximately $5.7 \mathrm{~m}^{3} \mathrm{~min}^{-1}$ (1500 gpm).

Methods. The basic test protocol was to evaluate changes in natural seawater after each unit process in the treatment system. Samples were obtained from sample ports located (1) prior to primary treatment (either hydrocyclone or self cleaning screen), (2) after primary treatment, but before secondary UV treatment, and (3) after secondary UV treatment. Each experimental run consisted of running water through the treatment train (hydrocyclone or self cleaning screen followed by UV treatment) at 1 of 3 turbidities: (1) low — ambient Biscayne Bay water (1 to 5 nephelometer turbidity units; NTU), (2) medium - ambient Biscayne Bay water with raised turbidity (30 to $50 \mathrm{NTU}$ ), and (3) high - ambient Biscayne Bay water with greatly raised turbidity (60 to 95 NTU). The turbidity was raised by adding a model clay, kaolinite, via an injection pump located prior to the turbidity meter and the inlet to the primary treatment units. The turbidity was monitored throughout the experiment, and kaolinite added as necessary to ensure constant turbidity. UV output was also monitored as described above. Three experimental runs were conducted at each of the 3 turbidity levels (low, medium, high) and each of the unit processes (hydrocyclone + UV, screen + UV) for a total of 18 runs. The experimental runs took place February through May 2001.

For a given test run, representative water samples were collected in $760 \mathrm{l}$ (200 gal) holding tanks filled from each sample port. In order to obtain a representative sample, each sample port was flushed for several minutes before the water sample was taken. Immediately after collection of the large volume samples in the 3 holding tanks, whole water samples were taken for the various analyses as described below. The holding tanks were then emptied through $35 \mu \mathrm{m}$ Nitex mesh plankton nets to concentrate the samples for zooplankton analyses.

Two sets of samples for the various biological and microbiological indices were collected during each experimental run: one set was collected immediately $(0 \mathrm{~h})$, and the second set was held in the holding tanks for $18 \mathrm{~h}$ at ambient temperature prior to analysis to determine longer-term effects of treatment. While the tanks were not covered during the $18 \mathrm{~h}$, the storage period took place primarily during the nighttime hours.

Biological protocols and statistical analysis. Biochemical analysis for viability of organisms: ATP content was used to assess the viability of organisms that were not removed by the hydrocyclone or screen. Size fractionated $(>35 \mu \mathrm{m}$ and $<35 \mu \mathrm{m})$ samples were collected on $0.45 \mu \mathrm{m}$ Durapore filters and immediately placed in boiling Tris buffer for extraction to avoid ATPase activity (Cheer et al. 1974). The samples were generally analyzed within $48 \mathrm{~h}$ or frozen until analysis. Once ATP is released, samples may be frozen with little loss of activity (Patterson et al. 1970). The ATP was analyzed with the Luciferin-luciferase assay (Holm-Hansen \& Booth 1966; Method 10200 I, American Public Health Association 1998) using a Turner TD20/20 luminometer. In order to relate ATP values to biomass, protein content was also measured on the same samples analyzed for ATP using a heated BiuretFolin assay (Dorsey et al. 1978).

Microbiological analysis: Microorganisms were enumerated using American Public Health Association (1998) protocols. Water samples were analyzed for total cultivable heterotrophic bacterial counts (Method 9215 D, heterotrophic plate count, membrane filter method), total coliforms and Escherichia coli (Method 9223 B, enzyme substrate coliform test). For total cultivable heterotrophic bacterial counts, 1 or $10 \mathrm{ml}$ of seawater sample were filtered through $0.45 \mu \mathrm{m}$ filters, and the filters placed on NWRI agar plates. The plates were incubated for $5 \mathrm{~d}$ at $24^{\circ} \mathrm{C}$ before counting visible colonies. Total coliforms and E. coli were enumerated using Colilert $18^{\circledast}$ (IDEXX Laboratories), a commercially available kit approved by the Standard Methods Committee for use in Method 9223. While these protocols were not specifically designed for optimizing growth of marine bacteria, they are used by local and state health departments for monitoring recreational waters, including naturally occurring marine environments. In addition, these protocols are used for compliance monitoring purposes under US Environmental Protection Agency (USEPA) Surface Water Treatment Rule (40 CFR 141.74).

Phytoplankton analysis: In our studies, the amount of $\mathrm{chl}$ a was used as an index of the biomass of viable phytoplankton. Our method for the analysis of chl $a$ and phaeophytin was based on Method 445.0 of Arar \& Collins (1992). The stated detection limit was $0.05 \mu \mathrm{gl}^{-1}$ for chl $a$ and $0.06 \mathrm{~g} \mathrm{l}^{-1}$ for phaeophytin in marine waters. Particulate matter was collected by filtration of 3 replicates (sample volume of $200 \mathrm{ml}$ ) at a vacuum of 5 inches $\mathrm{Hg}(<20 \mathrm{kPa})$ onto Whatman GF/F filters. If the analyses could not be conducted immediately, the filters were stored in individual plastic vials in a dessicator at $-20^{\circ} \mathrm{C}$. After chlorophyll and phaeophytin were extracted from the filters, the extractant was centrifuged at $1000 \times g$ for 5 min to clear the supernatant following the extraction period. The acetone was transferred to a $4 \mathrm{ml}$ glass cuvette and fluorescence was measured before and after acidification $(0.1 \mathrm{ml}$ of $0.1 \mathrm{~N} \mathrm{HCl})$ on a Turner Designs 
Model 10 fluorometer. The initial reading reflected the combined contribution of 'total' chl a while the final (acidified) reading was primarily phaeophytin (Smith et al. 1981).

Zooplankton analysis: Zooplankton samples were collected from $35 \mu \mathrm{m}$ mesh nets suspended in each of the 3 sample collecting tanks, as described above. The nets were custom manufactured (Sea-Gear) with a net mouth diameter of $0.75 \mathrm{~m}$ and a length of $1.45 \mathrm{~m}$ to allow suspension in the holding tanks. The sample cod-ends were rinsed with seawater filtered through a dual gradient (25 to $1 \mu \mathrm{m}$ ) cartridge (Cole Parmer) into $1 \mathrm{l}$ beakers for subsequent laboratory processing.

In the laboratory each beaker was sub-sampled for ATP analysis as described above, rinsed into a $500 \mathrm{ml}$ glass jar, treated with Neutral Red dye (JT Baker) for several minutes, and then preserved in a $4 \%$ buffered (sodium borate) formaldehyde solution. Neutral Red dye was selected for staining after several preliminary experiments in which samples were treated with Neutral Red, Rose Bengal, or Methylene Blue prior to and after fixation with formaldehyde. The purpose of these experimental treatments was to explore the use of a vital stain that would allow the separation and enumeration of dead or living specimens in samples prior to preservation, that were counted after preservation. Unfortunately, specimens appeared to continue taking up dye in all 3 cases after the sample was preserved (and specimens dead), leaving no indication of which specimens had been dead and which had been alive prior to preservation. Apparently in this case, recently dead organisms absorb the dye similarly to live organisms. The Neutral Red treatment yielded the greatest visual contrast between planktonic specimens and unidentifiable detrital particulate matter when compared with the 2 other dyes, and hence offered some advantage in processing samples containing large amounts of detritus, which the majority of samples included. All preserved samples were allowed to stand for at least $2 \mathrm{~d}$ prior to taxonomic enumeration to allow absorption of the stain. In addition, nearly all zooplankton samples were sub-sampled prior to fixation for brief microscopic surveys of apparent vitality of organisms.

Laboratory analyses of samples for taxonomic enumeration involved splitting each zooplankton sample several times in a Folsom splitter to obtain aliquots containing approximately 200 to 400 individuals. Three aliquots were counted with the aid of a Leica Wild M10 or Leica MS5 stereomicroscope for numerically dominant mesozooplankton taxa and groups. When an aliquot contained more than approximately 50 specimens of a species or taxon, that taxon was not counted in subsequent aliquots. The composition and number of species present determined the size of the second and third aliquots. For example, if the first aliquot contained 400 organisms of which 300 were copepod nauplii, then a larger aliquot was utilized for subsequent counts in order to obtain greater numbers of other species or groups. This method has been used in numerous studies conducted previously by Smith \& Lane (e.g. Smith et al. 1985, Smith \& Lane 1988, Flagg \& Smith 1989, Ashjian et al. 1995, 1997) and conforms in general to other recently published zooplankton sample enumeration guidelines (Postel et al. 2000). Previous net samples collected from the dock at the Rosenstiel School have often been dominated numerically by various stages of the small calanoid copepods Acartia tonsa and Paracalanus spp., and the small cyclopoid copepod genus Oithona (P. V. Z. Lane unpubl. data). We identified these and any other numerous copepods to the genus level. Other mesozooplanktic groups including chaetognaths, appendicularia, pteropods, and larvae of the decapod, echinoderm, bivalve and polychaete groups were counted if they were observed in samples.

Since zooplankton viability was not quantified in any of the experiments, evaluation of these populations after UV treatment was not conducted. In addition, zooplankton populations were not enumerated for the $18 \mathrm{~h}$ regrowth experiments because the time frame was considered too short for substantial growth and reproduction of zooplankton.

Experimental design and statistical analysis: A standard paired-sample design was employed in which samples taken pre- and post-primary unit process, and pre- and post-UV treatment during a single experimental run were considered as respective sample pairs. This design is a special case of a randomized complete block design where each experimental run is considered as a separate block (Montgomery 1997). Experimental treatments were the primary unit process type (50 $\mu \mathrm{m}$ screen or hydrocyclone) and corresponding UV treatment. The paired-sample block design was chosen to control for variation in response variables (e.g. ATP, total coliforms, chl $a$, etc.) among experimental runs, since each run was conducted at a different date and time and the seawater for each run was drawn from the natural environment. Turbidity level (low, medium, high) and sample analysis time ( 0 and $18 \mathrm{~h}$ after sampling) were incorporated as additional blocking variables in a factorial arrangement.

For each response variable, statistical analyses assessed 2 main aspects of unit process performance at the $0 \mathrm{~h}$ time point: (1) the performance of $50 \mu \mathrm{m}$ screen and hydrocyclone primary unit processes; and (2) the additional performance of UV treatment for each primary unit process. To understand the influence of sample analysis time, statistical analyses focused on assessing the change in a given response variable $18 \mathrm{~h}$ 
after 3 different levels of treatment, namely (1) no treatment, (2) primary treatment, and (3) primary treatment + UV treatment, for each treatment system (50 $\mathrm{mm}$ screen or hydrocyclone). The following additional aspects of performance were evaluated for both 0 and $18 \mathrm{~h}$ time points using a factorial analysis: (1) comparison of performance between treatment systems (50 $\mu \mathrm{m}$ screen vs. hydrocyclone), and (2) turbidity influence on treatment system performance. Statistical inference and hypothesis testing was conducted using the general linear model analysis framework (e.g. ANOVA, linear regression) for normally distributed or transformed-normal response variables (Neter et al. 1996). The normality assumption was evaluated by: (1) inspection of frequency histograms of general linear model error residuals, and (2) application of the Shapiro-Wilk test (Shapiro \& Wilk 1965). When necessary, response variables were corrected for normality using either the natural logarithm or square-root transformation. All statistical analyses and modeling were performed using the Statistical Analysis System software package (SAS Institute).

\section{RESULTS}

Statistical evaluation of treatment efficiency for the unit processes tested are presented in Table 1. This table shows a comparison of the unit processes, as well as any impact on each unit process due to turbidity effects. For the paired-sample experimental design, the main variable used in statistical tests was $d$, the difference in response-variable amount before and after treatment by a given unit process. Statistical significance for a unit process indicated that mean $d$ was different from zero. Statistical significance for turbidity impact indicated that mean $d$ differed among turbidity levels (low, medium, high).

It appeared that the physical separation processes, i.e. the $50 \mu \mathrm{m}$ screen and the hydrocyclone, each behaved differently with respect to reduction in the number of organisms that were affected by these systems, namely the zooplankton groups (Acartia spp., Paracalanus spp., Oithona spp., Harpacticoida, Copepoda nauplii, Gastropoda and Bivalvia larvae). A significant reduction in the number of all zooplankton monitored occurred with the screen $(p<0.01)$. There was some reduction in both gastropod and grouped invertebrate larvae counts with the hydrocyclone $(\mathrm{p}<0.01)$; otherwise, little removal was observed.

In all cases, the UV treatment unit appeared to be capable of significantly reducing $(p<0.01)$ bacterial populations (total cultivable heterotrophic bacteria, total coliforms, Escherichia coli), and in general, no turbidity effects were noted. Increased turbidity, hence decreased UV treatment dose, did not have a significant effect on bacterial abundance.

Table 1. Response variables vs. efficiency of unit process (time $=0 \mathrm{~h}$ ). Total bacteria: total cultivable heterotrophic bacteria; grouped invertebrate larvae: includes gastropod, bivalve, decapod and echinoderm larvae; N: no effect; ND: not determined;

${ }^{*}$ : significant at $<0.05 ;{ }^{* *}$ : significant at $<0.01 i^{* * *}$ : significant at $<0.001 ;-$ : insufficient data for statistical analysis

\begin{tabular}{|c|c|c|c|c|c|c|c|c|}
\hline \multirow[b]{3}{*}{ Response variable } & \multicolumn{8}{|c|}{ - Unit process } \\
\hline & \multicolumn{2}{|c|}{ Screen } & \multicolumn{2}{|c|}{ Screen + UV } & \multicolumn{2}{|c|}{ Hydrocyclone } & \multicolumn{2}{|c|}{ Hydrocyclone + UV } \\
\hline & $\begin{array}{l}\text { Turbidity } \\
\text { impact }\end{array}$ & $\begin{array}{l}\text { Signif. } \\
\text { reduction }\end{array}$ & $\begin{array}{l}\text { Turbidity } \\
\text { impact }\end{array}$ & $\begin{array}{l}\text { Signif. } \\
\text { reduction }\end{array}$ & $\begin{array}{l}\text { Turbidity } \\
\text { impact }\end{array}$ & $\begin{array}{l}\text { Signif. } \\
\text { reduction }\end{array}$ & $\begin{array}{l}\text { Turbidity } \\
\text { impact }\end{array}$ & $\begin{array}{l}\text { Signif. } \\
\text { reduction }\end{array}$ \\
\hline Total bacteria & $\mathrm{N}$ & $\mathrm{N}$ & $\mathrm{N}$ & $* *$ & $\mathrm{~N}$ & $*$ & $\mathrm{~N}$ & $* * *$ \\
\hline Total coliforms & $\mathrm{N}$ & $\mathrm{N}$ & $\mathrm{N}$ & $* * *$ & $\mathrm{~N}$ & $\mathrm{~N}$ & * & $* * *$ \\
\hline Escherichia coli & $\mathrm{N}$ & $\mathrm{N}$ & $\mathrm{N}$ & $* * *$ & $\mathrm{~N}$ & $\mathrm{~N}$ & $\mathrm{~N}$ & $* * *$ \\
\hline Total chl a & $\mathrm{N}$ & $\mathrm{N}$ & $\mathrm{N}$ & $\mathrm{N}$ & $\mathrm{N}$ & $\mathrm{N}$ & * & ** \\
\hline Total phaeophytin & $\mathrm{N}$ & $\mathrm{N}$ & $\mathrm{N}$ & $\mathrm{N}$ & $\mathrm{N}$ & $\mathrm{N}$ & $\mathrm{N}$ & $\mathrm{N}$ \\
\hline $\begin{array}{l}\text { Acartia spp. } \\
\text { (Order Calanoida) }\end{array}$ & $\mathrm{N}$ & $* * *$ & ND & ND & $\mathrm{N}$ & $\mathrm{N}$ & ND & ND \\
\hline $\begin{array}{l}\text { Paracalanus spp. } \\
\text { (Order Calanoida) }\end{array}$ & $\mathrm{N}$ & ${ }^{* *}$ & ND & ND & * & $\mathrm{N}$ & ND & ND \\
\hline $\begin{array}{l}\text { Oithona spp. } \\
\text { (Order Cyclopoida) }\end{array}$ & $\mathrm{N}$ & ${ }^{* * *}$ & ND & ND & $\mathrm{N}$ & $\mathrm{N}$ & ND & ND \\
\hline Order Harpacticoida & $\mathrm{N}$ & $* * *$ & ND & ND & $\mathrm{N}$ & $\mathrm{N}$ & ND & ND \\
\hline Class Copepoda nauplii & $\mathrm{N}$ & ** & ND & ND & $\mathrm{N}$ & $\mathrm{N}$ & ND & ND \\
\hline Class Gastropoda larvae & $\mathrm{N}$ & $* * *$ & ND & ND & $\mathrm{N}$ & ** & ND & ND \\
\hline Class Bivalvia larvae & $\mathrm{N}$ & ** & ND & ND & $\mathrm{N}$ & $\mathrm{N}$ & ND & ND \\
\hline $\begin{array}{l}\text { Grouped invertebrate } \\
\text { larvae }\end{array}$ & $\mathrm{N}$ & $* * *$ & ND & ND & $\mathrm{N}$ & ${ }^{* *}$ & ND & ND \\
\hline Protein $(>35 \mu \mathrm{m})$ & $\mathrm{N}$ & $* * *$ & - & - & $\mathrm{N}$ & * & - & - \\
\hline Protein $(<35 \mu \mathrm{m})$ & - & - & - & - & - & - & - & - \\
\hline
\end{tabular}


The statistical evaluation for the test system comprising the $50 \mu \mathrm{m}$ screen plus the UV unit, and considering the $18 \mathrm{~h}$ incubation period after treatment, is presented in Table 2. There appeared to be no effect from turbidity enhancement on any of the unit processes. Over the entire test scenario, the only effects were noted for UV treatment on total cultivable heterotrophic bacteria, total coliforms and E. coli, and on chl a used as a surrogate for phytoplankton biomass, and total phaeophytin. Significant increases in bacterial numbers were observed $(p<0.05)$ while significant decreases in phytoplankton biomass occurred during the $18 \mathrm{~h}$ incubation $(\mathrm{p}<0.01)$.

The statistical evaluation of data collected after an $18 \mathrm{~h}$ incubation period for the hydrocyclone plus UV treatment is shown in Table 3. Again, only after UV treatment were the majority of significant changes in the measured parameters observed. Similar to the results reported above for screen plus UV, it was noted that a significant increase in growth of bacteria, and significant decrease in phytoplankton biomass, occurred after the $18 \mathrm{~h}$ incubation.

The effect of ballast water treatment schemes was evaluated against bacterial populations and phyto- plankton biomass in ambient seawater (Fig. 2). Because there were no turbidity effects (see Tables 1 \& 2), the data for bacterial populations or phytoplankton biomass were grouped, respectively, for this analysis. The relative concentrations of total cultivable heterotrophic bacteria and coliforms remained unchanged from the ambient seawater through the physical separation processes (10 to 40 cells $\mathrm{ml}^{-1}$ ), as shown in Fig. 2a. This result was expected, as neither of these processes was intended to remove material the size of bacteria (1 to $2 \mu \mathrm{m}$ ). UV treatment following the separation processes, however, decreased the abundance

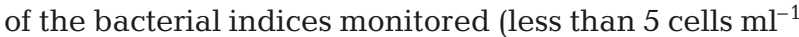
for total cultivable heterotrophic bacteria, and below the detection limit of 10 cells $100 \mathrm{ml}^{-1}$ for total coliforms and Escherichia coli).

Levels of chl a ( 0.5 to $\left.0.7 \mu \mathrm{g} \mathrm{l}^{-1}\right)$ were not affected by physical separation processes, and in contrast to the observations noted for bacterial populations, only slightly affected by UV treatment (Fig. 2b). This figure also shows that phaeophytin levels (about $0.4 \mu \mathrm{g} \mathrm{l}^{-1}$ ) remained constant throughout all analyses. Phaeophytin is composed of a suite of chlorophyll degradation products and is often used as an index to the

Table 2. Response variables vs. efficiency of screen with UV system (time $=18 \mathrm{~h}$ ). Total bacteria: total cultivable heterotrophic bacteria; I: increase; D: decrease; $\mathrm{N}$ : no effect; ${ }^{*}$ : significant at $<0.05 ;{ }^{* *}$ : significant at $<0.01$; ${ }^{* * *}$ : significant at $<0.001$; -: insufficient data for statistical analysis

\begin{tabular}{|c|c|c|c|c|c|c|}
\hline \multirow[b]{3}{*}{ Response variable } & & & \multirow{2}{*}{\multicolumn{2}{|c|}{$\begin{array}{l}\text { Unit process } \\
\text { Screen }\end{array}$}} & \multirow{2}{*}{\multicolumn{2}{|c|}{ Screen + UV }} \\
\hline & \multicolumn{2}{|c|}{ Ambient water } & & & & \\
\hline & $\begin{array}{c}\text { Turbidity } \\
\text { impact }\end{array}$ & $\begin{array}{l}\text { Change } \\
\text { after } 18 \mathrm{~h}\end{array}$ & $\begin{array}{c}\text { Turbidity } \\
\text { impact }\end{array}$ & $\begin{array}{l}\text { Change } \\
\text { after } 18 \mathrm{~h}\end{array}$ & $\begin{array}{l}\text { Turbidity } \\
\text { impact }\end{array}$ & $\begin{array}{l}\text { Change } \\
\text { after } 18 \mathrm{~h}\end{array}$ \\
\hline Total bacteria & $\mathrm{N}$ & $\mathrm{I}^{*}$ & * & _- & $\mathrm{N}$ & $\mathrm{I}^{*}$ \\
\hline Total coliforms & $\mathrm{N}$ & $\mathrm{N}$ & $\mathrm{N}$ & $\mathrm{N}$ & $\mathrm{N}$ & $\mathrm{I}^{*}$ \\
\hline Escherichia coli & $\mathrm{N}$ & $\mathrm{N}$ & $\mathrm{N}$ & $\mathrm{N}$ & $\mathrm{N}$ & $I^{*}$ \\
\hline Total chl a & $\mathrm{N}$ & $I^{*}$ & $\mathrm{~N}$ & $I^{*}$ & $\mathrm{~N}$ & $\mathrm{D}^{* *}$ \\
\hline Total phaeophytin & $\mathrm{N}$ & $\mathrm{N}$ & $\mathrm{N}$ & $\mathrm{D}^{* *}$ & $\mathrm{~N}$ & $\mathrm{D}^{* * *}$ \\
\hline Protein $(>35 \mu \mathrm{m})$ & $\mathrm{N}$ & $\mathrm{N}$ & $\mathrm{N}$ & $\mathrm{N}$ & $\mathrm{N}$ & $\mathrm{N}$ \\
\hline Protein $(<35 \mu \mathrm{m})$ & $\mathrm{N}$ & $\mathrm{N}$ & $\mathrm{N}$ & $D^{*}$ & $\mathrm{~N}$ & $\mathrm{~N}$ \\
\hline
\end{tabular}

Table 3. Response variables vs. efficiency of hydrocyclone and UV system (time $=18 \mathrm{~h}$ ). Total bacteria: total cultivable heterotrophic bacteria; I: increase; D: decrease; N: no effect; ${ }^{*}$ : significant at $<0.05_{;}{ }^{* * *}$ : significant at $<0.001$

\begin{tabular}{|c|c|c|c|c|c|c|}
\hline \multirow[b]{2}{*}{ Response variable } & \multicolumn{2}{|c|}{ Ambient water } & \multicolumn{2}{|c|}{$\begin{array}{l}\text { - Unit process } \\
\text { Hydrocyclone }\end{array}$} & \multicolumn{2}{|c|}{ Hydrocyclone UV } \\
\hline & $\begin{array}{l}\text { Turbidity } \\
\text { impact }\end{array}$ & $\begin{array}{l}\text { Change } \\
\text { after } 18 \mathrm{~h}\end{array}$ & $\begin{array}{c}\text { Turbidity } \\
\text { impact }\end{array}$ & $\begin{array}{l}\text { Change } \\
\text { after } 18 \mathrm{~h}\end{array}$ & $\begin{array}{c}\text { Turbidity } \\
\text { impact }\end{array}$ & $\begin{array}{l}\text { Change } \\
\text { after } 18 \mathrm{~h}\end{array}$ \\
\hline Total bacteria & $\mathrm{N}$ & $\mathrm{N}$ & $D^{*}$ & $\mathrm{~N}$ & $\mathrm{~N}$ & $\mathrm{I}^{* * *}$ \\
\hline Total coliforms & $\mathrm{N}$ & $\mathrm{N}$ & $\mathrm{N}$ & $\mathrm{N}$ & $\mathrm{N}$ & $\mathrm{I}^{* * *}$ \\
\hline Escherichia coli & $\mathrm{N}$ & $\mathrm{N}$ & $\mathrm{N}$ & $\mathrm{N}$ & $\mathrm{N}$ & $\mathrm{I}^{*}$ \\
\hline Total chl a & $\mathrm{N}$ & $\mathrm{N}$ & $\mathrm{N}$ & $\mathrm{I}^{*}$ & $\mathrm{D}^{*}$ & $\mathrm{D}^{* * *}$ \\
\hline Total phaeophytin & $\mathrm{N}$ & $\mathrm{D}^{*}$ & $\mathrm{~N}$ & $\mathrm{~N}$ & $\mathrm{~N}$ & $\mathrm{D}^{* * *}$ \\
\hline Protein $>35 \mu \mathrm{m}$ ) & $\mathrm{N}$ & $\mathrm{N}$ & $\mathrm{N}$ & $\mathrm{N}$ & $\mathrm{N}$ & $\mathrm{N}$ \\
\hline Protein $(<35 \mu \mathrm{m})$ & $\mathrm{N}$ & $\mathrm{N}$ & $\mathrm{N}$ & $\mathrm{N}$ & $\mathrm{N}$ & $\mathrm{N}$ \\
\hline
\end{tabular}



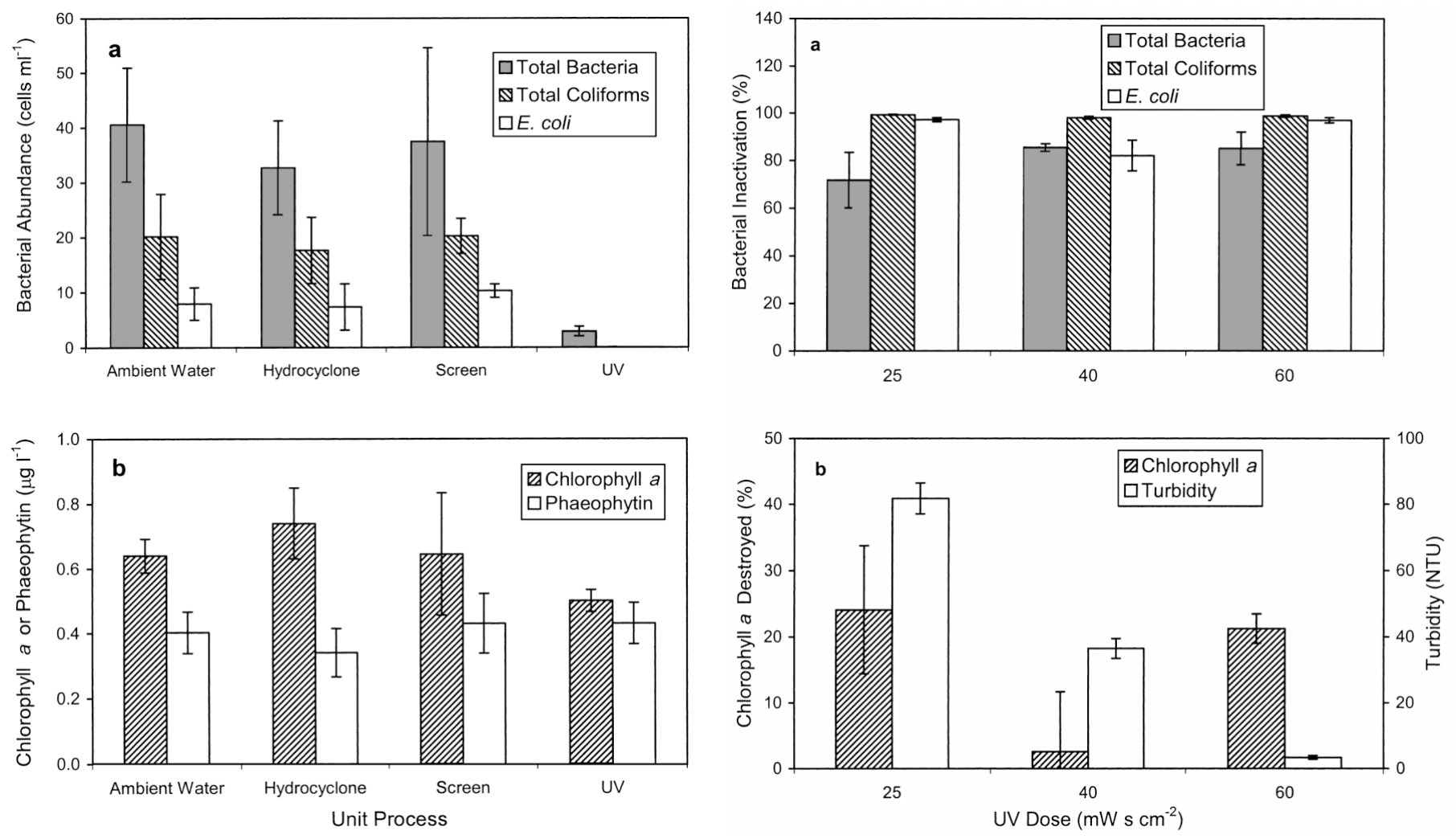

Fig. 2. Effect of treatment processes on (a) bacterial abundance, and (b) phytoplankton biomass. Total Bacteria indicates total cultivable heterotrophic bacteria. Samples were collected at $0 \mathrm{~h}$, immediately after treatment. Error bars represent $\pm 1 \mathrm{SE}$

detrital or dead material (Smith et al. 1981). It was anticipated that if phytoplankton inactivation occurred, then perhaps it could be monitored by the appearance of phaeophytin. We did not observe changes in phaeophytin concentrations, thereby negating its use in our studies as an indicator of chlorophyll breakdown.

The effect of added turbidity in the test system on bacterial inactivation and chl a destruction is shown in Fig. 3a and b, respectively. The dose delivered by the UV system varied from approximately $60 \mathrm{~mW} \mathrm{~s} \mathrm{~cm}^{-2}$ to $25 \mathrm{~mW} \mathrm{~s} \mathrm{~cm}^{-2}$ due to added suspended solids. There was little effect of different UV doses on inactivation of any of the bacterial groups tested (Fig. 3a). Similar to the results observed for bacteria, there were no apparent trends with respect to destruction of chl $a$ with either increasing or decreasing UV dose (Fig. 3b).

Bacterial populations, depicted here as the relative population present after $18 \mathrm{~h}$, exhibited significant regrowth after UV treatment, regardless of the dose delivered (Fig. 4a). In fact, it was noted that the viable population of all bacterial groups tested after $18 \mathrm{~h}$ of regrowth was between 10 and 100 times the population monitored directly after initial UV dose at $0 \mathrm{~h}$.

Fig. 3. Effect of UV dose on (a) bacterial inactivation, and (b) phytoplankton destruction. Total Bacteria indicates total cultivable heterotrophic bacteria. The highest turbidities correspond to the lowest UV dose. Samples were collected at $0 \mathrm{~h}$, immediately after treatment. Error bars represent $\pm 1 \mathrm{SE}$

As observed with bacteria, the amount of chl $a$ and phaeophytin $18 \mathrm{~h}$ after treatment also did not change as a function of the UV dose delivered (Fig. 4b). As noted above and with the short incubation times used in our study, phaeophytin was not a sensitive indicator of deleterious effects to the phytoplankton population. This figure also shows that the remaining chlorophyll in samples $18 \mathrm{~h}$ after treatment was approximately half of that at $0 \mathrm{~h}$, indicating some loss in chlorophyll upon incubation, and therefore, possible injury to phytopigments due to UV treatment. Longer phytoplankton incubation times would be required to determine the extent of biomass reduction achievable by UV treatment.

In addition to bacteria and phytoplankton, zooplankton assemblages were also monitored as a function of treatment type and added suspended solids. The zooplankton species observed during our studies were those most commonly found in Biscayne Bay seawater samples during the test period. These included gastropod and bivalve larvae, copepod nauplii, members of the order Harpacticoida and representative species of the Genera Oithona, Paracalanus, and Acartia. Other organisms were observed but were not present con- 

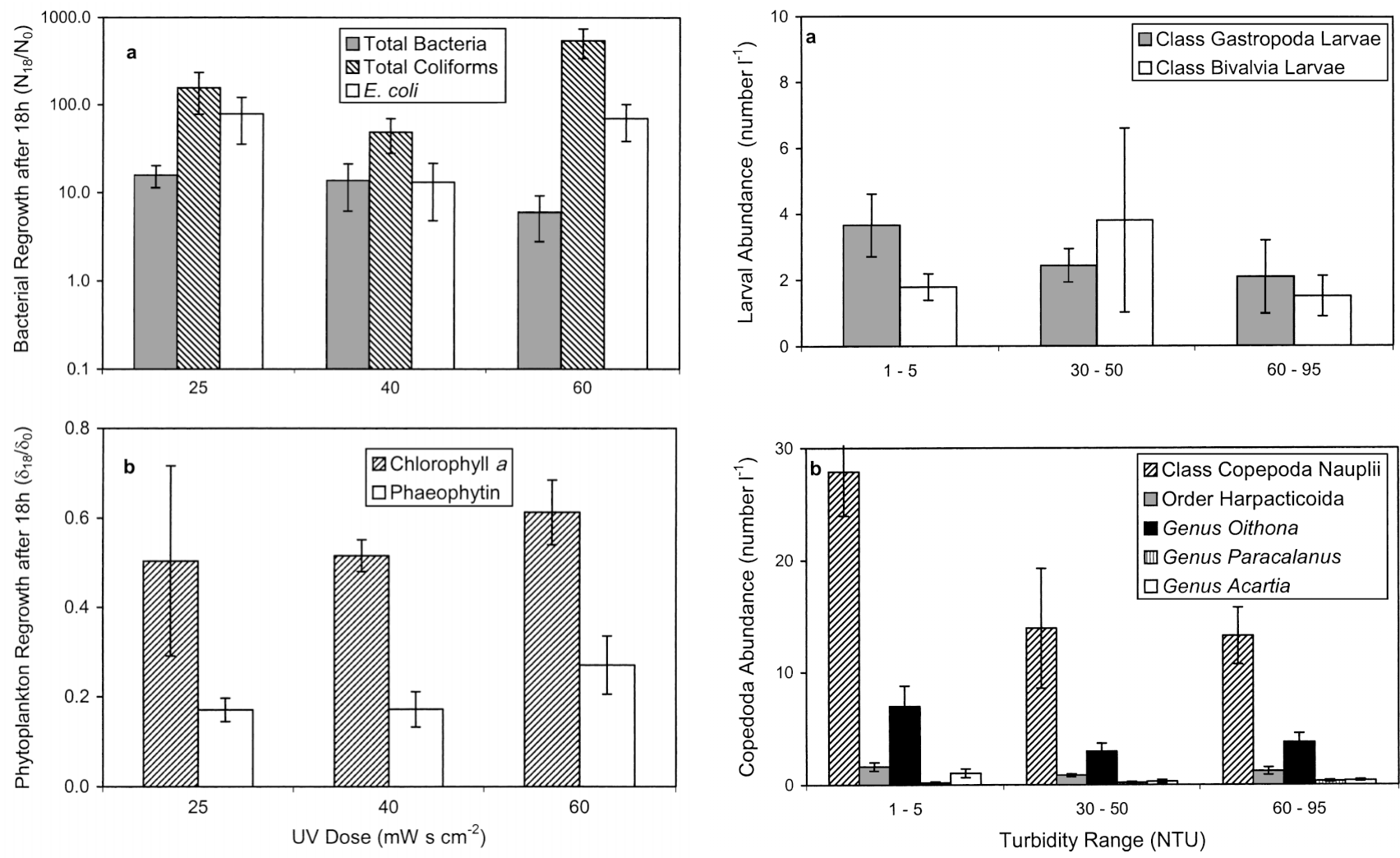

Fig. 4. Regrowth of (a) bacterial, and (b) phytoplankton populations after storage for $18 \mathrm{~h}$. Total bacteria indicates total cultivable heterotrophic bacteria. $N_{18} / N_{0}=$ number of bacteria at $18 \mathrm{~h}$ divided by the number of bacteria at $0 \mathrm{~h} . \delta_{18} / \delta_{0}=$ amount of chl $\mathrm{a}$ or phaeophytin at $18 \mathrm{~h}$ divided by the amount at $0 \mathrm{~h}$. Error bars represent $\pm 1 \mathrm{SE}$

sistently or in large enough numbers to be analyzed statistically. Qualitative microscopic observations of untreated vs. separation treated (screen or hydrocyclone), or separation plus UV treated samples, made immediately following sample collection, revealed no apparent loss of vitality by any zooplankton groups observed in the samples. That is, virtually all samples contained lively specimens, regardless of the treatment method. These observations suggest that the UV treatment utilized here was not sufficient to immediately kill the mesozooplankton. In 4 out of 18 experimental runs, there was reduced vitality of zooplankton in UV-treated samples held for $18 \mathrm{~h}$. However in the rest of the $18 \mathrm{~h}$ UV-treated samples, lively specimens comparable to those seen in ambient water and separation treated samples were noted. It must be emphasized that these observations are qualitative and of a subjective nature.

The abundance in Biscayne Bay waters of selected zooplankton species used to monitor treatment efficiency is presented in Fig. 5. Each figure represents zooplankton numbers pooled from ambient, pre-

Fig. 5. Ambient concentrations of (a) gastropod and bivalve larvae, and (b) copepod species at the 3 turbidity levels (NTU $=$ nephelometer turbidity units). Samples were collected immediately after treatment at $0 \mathrm{~h}$. Error bars represent $\pm 1 \mathrm{SE}$

treatment data from both hydrocyclone and selfcleaning screen test-runs. The typical concentration of gastropod and bivalve larvae was small, averaging

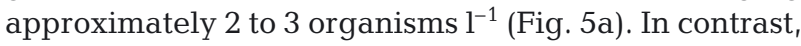
a relatively large number of Copepoda nauplii were present $\left(>10\right.$ organisms $\mathrm{l}^{-1}$ ) in Biscayne Bay waters while other copepods were less abundant, quite often less than 1 to 2 organisms $1^{-1}$ (Fig. 5b).

The removal efficiency of both gastropod and bivalve larvae by screen and hydrocyclonic treatment is shown in Fig. 6. It is noted that the screen consistently removed over $90 \%$ of the larvae, regardless of the level of suspended solids in the water. Considering that most of the larvae analyzed during this study were substantially larger than $50 \mu \mathrm{m}$, it was anticipated that the majority of the larvae would be removed. In contrast, the overall removal of larvae by the hydrocyclone was low (10 to $40 \%$ ), although there appears to be an increasing trend in removal efficiency as a function of suspended solids.

As with the bivalve and gastropod larvae, the screen removed 60 to $95 \%$ of copepods while the hydrocyclone was ineffective (Fig. 7). The copepods investi- 


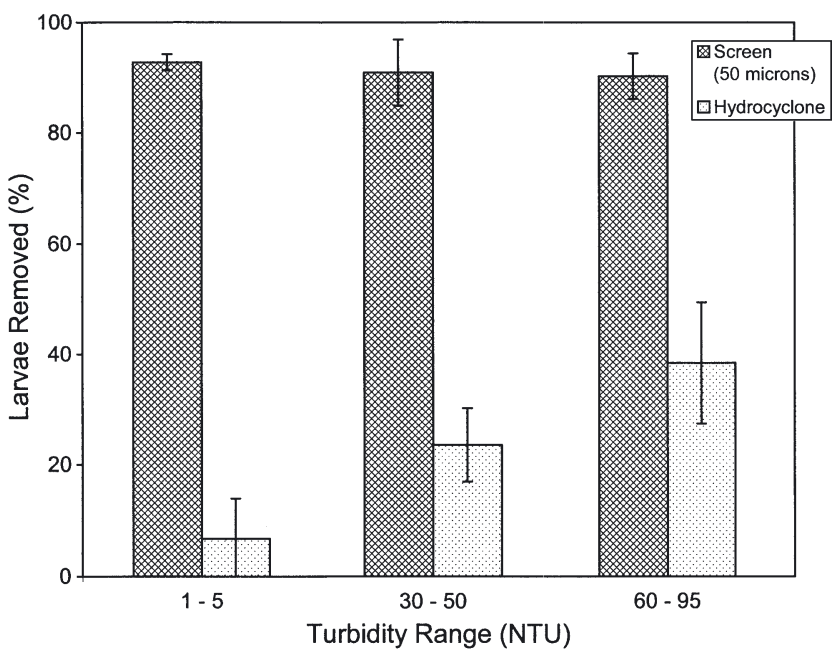

Fig. 6. Physical removal of gastropod and bivalve larvae by screen and hydrocyclone at the 3 different turbidity levels (NTU $=$ nephelometer turbidity units). Samples were collected immediately after treatment at $0 \mathrm{~h}$. Error bars represent $\pm 1 \mathrm{SE}$

gated in this study were generally smaller in size than the gastropod and bivalve larvae; however, they were still removed by the $50 \mu \mathrm{m}$ screen. It can also be noted that although there was variation in the enumeration of organisms after hydrocyclone treatment, the removal of organisms via the hydrocyclone was clearly small, and less than $15 \%$.

Biochemical analyses (ATP and protein) were also conducted to evaluate their usefulness in monitoring treatment efficiency. The intention was to determine whether these methods could provide an overall estimate of activity and biomass of all plankton in a sample. Protein and ATP were monitored in 2 different components ( $>35$ and $<35 \mu \mathrm{m}$ ) of seawater. The larger fraction represents zooplankton groups and other larger organisms, while the smaller fraction represents principally the microbiota. Protein concentration as a function of treatment process for both size fractions is shown in Fig. 8a. There was approximately 5000 times more protein in the smaller vs. the larger fraction. For that component of the biota larger than $35 \mu \mathrm{m}$, there was significant removal of protein by the screen $(p<0.001)$ and hydrocyclone $(p<0.05)$. This was to be expected, as differences in protein should only be observed if biomass is removed, as would be the case after hydrocyclone or screen treatment. It was not anticipated that a change in protein would be noted due to UV treatment. For the smaller fraction, there was little change in protein concentration. This was also to be expected, as the physical separation processes were not expected to remove organisms of this size fraction. Similar to the results for protein, Fig. 8b shows that for ambient seawater, ATP concentrations were approximately 1000 times higher in the

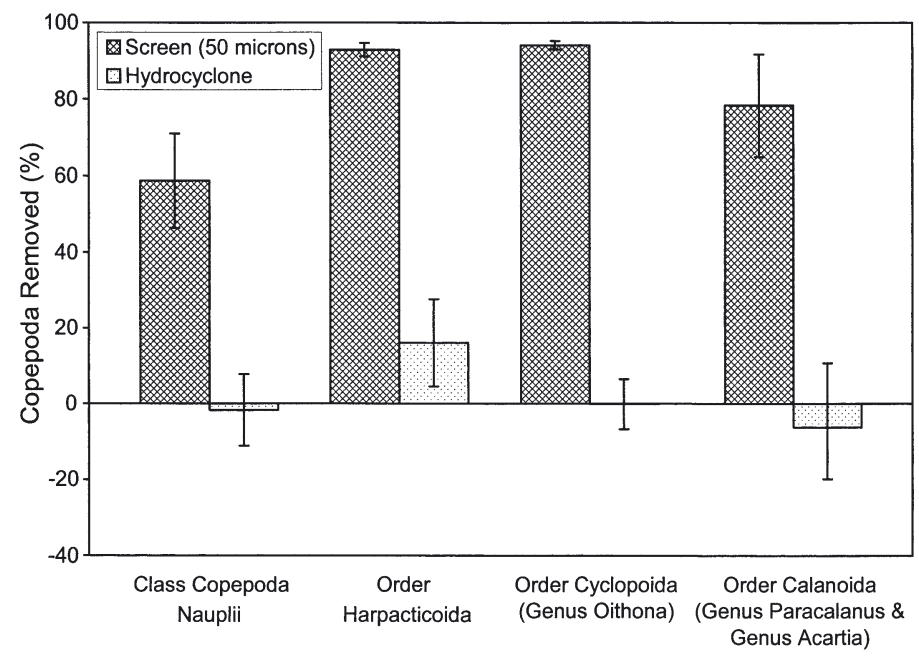

Fig. 7. Physical removal of Copepoda species by screen vs. hydrocyclone. These data were grouped from all turbidity levels (NTU = nephelometer turbidity units). Samples were collected immediately after treatment at $0 \mathrm{~h}$. Error bars represent $\pm 1 \mathrm{SE}$

smaller vs. the larger fraction. The amount of ATP in the larger fraction decreased after the physical separation processes of hydrocyclone and screen, and remained constant after UV treatment. ATP concentrations in the small fraction did not change after the physical separation processes, and contrary to expectations, did not decrease after UV treatment. This was unexpected, as significant decreases were noted in all bacterial indices monitored after UV treatment. The large variability encountered in ATP measurements may partly account for this result; moreover, we were not able to obtain sufficient ATP data for statistical evaluation.

\section{DISCUSSION}

The results of our study showed that the screen removed the majority of zooplankton, and UV treatment decreased the abundance of bacteria monitored. Turbidity influence (increased suspended solids) on the unit processes was also evaluated, with the expectation that turbidity would likely have the greatest effect on the amount of UV delivered to seawater. While operational effects were noted for the screen and hydrocyclone, there was little effect of increased turbidity on bacterial abundance. This is likely due to the fact that even at the highest turbidities, a sufficient UV dose was still available to inactivate bacteria. Because the UV treatment system in our experiments was designed to deliver a dose in excess of $60 \mathrm{~mW} \mathrm{~s} \mathrm{~cm}{ }^{-2}$ in ambient seawater, at the highest suspended solids concentrations (60 to $95 \mathrm{NTU}$ ) tested, a UV dose in excess of $25 \mathrm{~mW} \mathrm{~s} \mathrm{~cm}^{-2}$ was measured. This dose has been reported in other 

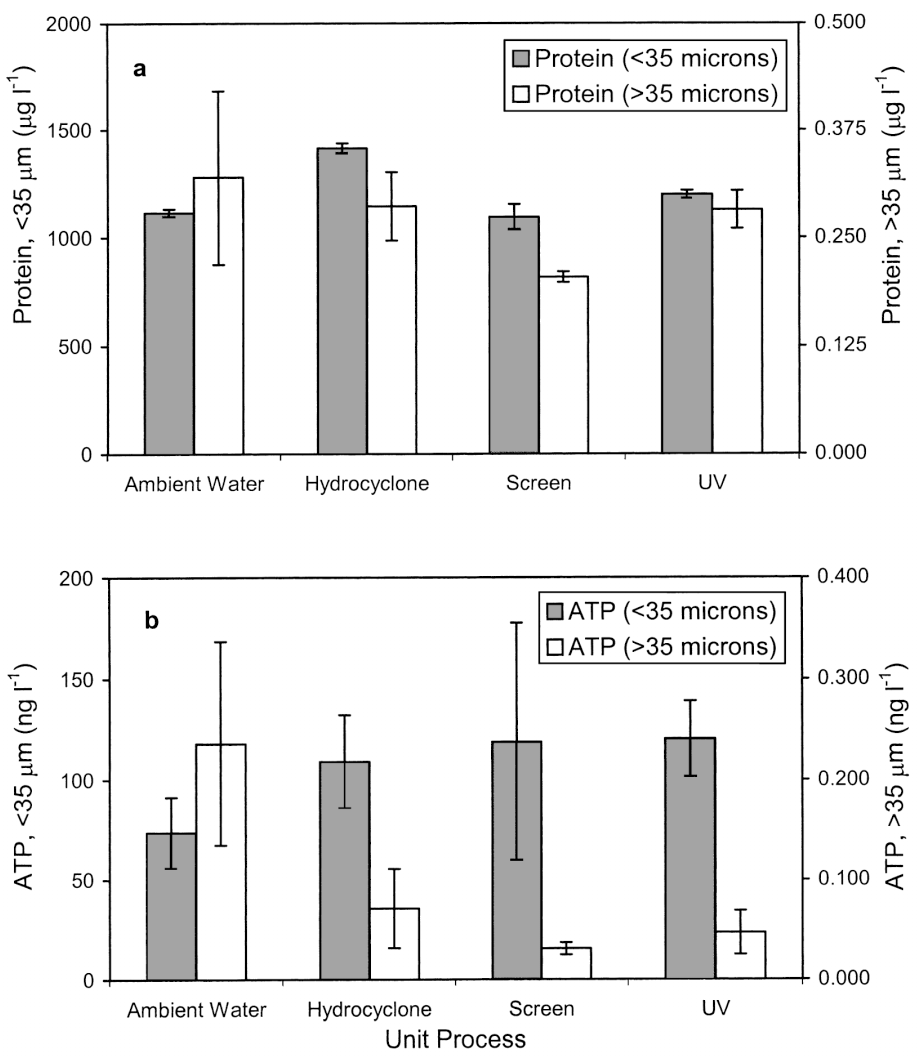

Fig. 8. Effect of treatment processes on (a) protein, and (b) ATP of organisms in $<35$ and $>35 \mu \mathrm{m}$ fractions. These data were grouped from all turbidity levels (NTU = nephelometer turbidity units). Samples were collected immediately after treatment at $0 \mathrm{~h}$. Error bars represent $\pm 1 \mathrm{SE}$

studies to reduce bacterial numbers significantly (e.g. Scheible et al. 1983). It also should be noted here that the test range of added suspended solids (up to $95 \mathrm{NTU})$ is in excess of any found in the natural environment. In general, the most turbid waters naturally encountered are in the range of 10 to 15 NTU.

The UV system facilitated significant removal of bacteria, with essentially all of the coliforms (total and Escherichia coli) being removed to below detection levels (10 organisms per $100 \mathrm{ml}$ ), and only a small residual of total cultivable heterotrophic bacteria remaining in the water. These data indicate that UV treatment will be effective at significantly reducing bacterial populations, and that the effects of pretreatment via screens or hydrocyclones will not be required in order to enhance removal efficiencies of a UV system. However, the effectiveness of UV treatment was short-lived, as bacterial regrowth occurred after the samples were held for $18 \mathrm{~h}$. One possible explanation for this result is that bacteria are capable of repairing genetic damage induced by UV treatment (Kelner 1949, Lawrence \& Block 1968, Scheible et al. 1983), and this phenomenon may have also occurred in our study. Another possible explanation is that $100 \%$ mortality did not actually occur, and the remaining cells (few yet intact) were sufficient to increase the population to higher than ambient levels over an $18 \mathrm{~h}$ period.

It should also be noted that total coliform and Escherichia coli abundances in Biscayne Bay were high (2000 cells per $100 \mathrm{ml}$ ), and exceeded by 2 orders of magnitude the USEPA criterion of 35 cells per $100 \mathrm{ml}$. A possible explanation for the high counts is that non-coliform bacteria naturally present in seawater have recently been shown to be responsible for false positive results in the enzyme substrate method used for detecting coliforms (Pisciotta et al. 2002). Although the use of Colilert $18^{\circledR}$ system (IDEXX Laboratories) has been approved by the USEPA for drinking water monitoring, it appears that in subtropical seawater samples, coliform abundances may be overestimated by 1 to 2 orders of magnitude.

All of the data relating to phytoplankton chlorophyll were grouped in order to compare UV effects as a function of introduced turbidity. This was possible because no effects on phytoplankton biomass due to physical separation treatment were observed. It appears that the use of UV treatment for destroying phytoplankton in ballast water would not be an efficient or predictable process, and probably would not be successful in producing ballast water free of phytoplankton. However, it should also be noted that chl $a$ is effectively a monitor of biomass and may not be a sensitive measure of inactivation of photosynthetic activity due to UV treatment. It is known that even if a vegetative cell is inactivated, it takes some time (hours to days) before the chlorophyll present in the cell is reduced or disappears altogether. Sutherland et al. (2001) conducted longer term (16 d) incubation studies, and found that the starting concentration, growth rate, and relative abundance of Chaetoceros gracile were reduced in UV-treated samples.

Obviously, the issue of regrowth is significant and must be addressed if UV treatment is to be considered as a technology to reduce microorganism abundance in ballast water. It should also be noted that in other applications (e.g. drinking water treatment), typical water treatment technologies require that treatment efficacy be substantial and far in excess of that required to reduce natural populations of microorganisms by only 2 to 3 orders of magnitude as seen in our study. For example, if water is to be treated to remove bacterial populations in the range of $10^{3}$ organisms per $\mathrm{ml}$, then treatment to facilitate at least 6 -logs reduction is required in order for the process to be considered reliable and viable. Thus, if UV treatment is to be used as a treatment technology, the dose required will need to be in excess of that utilized in this experiment (>60 $\mathrm{mW} \mathrm{s} \mathrm{cm}^{-2}$ ) to guarantee reliable and predictable 
removal of microorganisms. Clearly, the regrowth issue observed here will mean that the required UV dose would have to be excessively high to ensure that all organisms are permanently inactivated.

It is clear that the $50 \mu \mathrm{m}$ screen was more effective than the hydrocyclone for removing zooplankton and larvae monitored in our study. In contrast to the results obtained by Sutherland et al. (2001) for a hydrocyclone-UV treatment system, visual observations indicated no loss of vitality of any zooplankton groups after treatment. There was, however, a trend of increasing removal efficiency at higher turbidity levels with the hydrocyclone. One possible explanation for this observation is that the added kaolinite clay was aggregating larvae into a large enough mass to be affected by the hydrocyclone and therefore, removed. In fact, visual observation of samples after addition of clay showed that much of the larvae were indeed aggregated together. Even with a large load of suspended solids, with turbidities close to 90 NTU, less than $40 \%$ of the larvae were removed by the hydrocyclone. Considering that the majority of invasions recorded to date have occurred because of transport of bivalve and gastropod larvae (Ruiz et al. 2000b), removal of these particular components of the zooplankton becomes especially important. From our studies, it appears that a screen operating at $50 \mu \mathrm{m}$ can effectively remove the majority of larvae present in natural water systems.

While the measurement of biomass can be achieved in many ways, the determination of organism viability or activity is a more critical monitor. Other than for organisms such as bacteria, where plate growth studies can be easily undertaken, it is difficult to determine the viability of larger organisms on a routine basis. In order to address this issue, ATP was used as a monitor of organism activity. ATP is an important macromolecule used by live organisms in carrying out their biochemical processes, and quickly disappears upon the death of an organism. ATP analysis provides the only means of determining total viable plankton biomass (American Public Heath Association 1998) and has had wide application in estimating living biomass in sediments (Karl \& LaRock 1975), sludge (Patterson et al. 1970), marine water columns (Holm-Hansen \& Booth 1966, Maranda \& Lacroix 1983), as well as in phytoplankton (Holm-Hansen 1969, Hitchcock et al. 1987) and bacterial populations (Lundin \& Thore 1975). Protein was also measured in the same samples taken for ATP analysis in order to relate viability (as measured by ATP) to biomass. The intent was to explore the use of these relatively easy monitoring methods, with the idea that they may eventually be used onboard ships, most of which are not equipped with wet labs. Kits to measure protein are commercially available, and the ATP method has the potential to be developed into a flow-through, online monitoring system.
ATP values observed in Biscayne Bay water (50 to 120 $\mathrm{ng} \mathrm{\textrm {l } ^ { - 1 }}$ ) for the small fraction $(<35 \mu \mathrm{m})$ were consistent with that for a subtropical estuarine system. Other studies have reported ATP concentrations in bacterioplankton from $114 \mathrm{ng} \mathrm{l}^{-1}$ in a coral atoll (Blanchot et al. 1989) to 0.5 to $2 \mu \mathrm{g} \mathrm{l}^{-1}$ in eutrophic coastal waters near Alexandria, Egypt (Aboul-Kassim et al. 1992). ATP values for bacterioplankton are typically reported to be greater by 1 order of magnitude than concentrations found for larger planktonic organisms (Maranda \& Lacroix 1983), and this was also observed in our study. Our results also indicate that decreased ATP levels were consistent with biomass removal, thus ATP levels reflected changes that occurred due to treatment. In the case of ATP concentrations in the small fraction, it was noted that ATP levels remained constant through the physical separation processes. This was as expected, since organisms smaller than $35 \mu \mathrm{m}$ would not be removed by these processes. However, ATP concentrations in this fraction remained high after UV treatment, even though all other monitors (e.g. bacterial counts) indicated that organism abundance was significantly reduced due to UV treatment. The preliminary data presented here indicate that ATP may be a useful tool for monitoring activity of the biomass, as affected by treatment processes. However, more work is required to refine the procedure so that reliable and reproducible data can be collected.

Acknowledgements. We thank J. Jurado, L. Llinas, K. Callwood, J. Baker and L. Lundsten for able technical assistance. We also thank P. Herring of United States Coast Guard Research and Development Center for comments on the manuscript. This project was funded by the United States Coast Guard Research and Development Center (Contract DTCG39-00-C-R0010).

\section{LITERATURE CITED}

Aboul-Kassim TA, Dowidar NM, El-Nady FE, Abdel-Moati AR (1992) Adenosine triphosphate (ATP) and chlorophyll a biomass as eutrophication indices in one of the most polluted basins off Alexandria coastal waters, Egypt. In: Vollenweider RA, Marchetti R, Viviani R (eds) Marine coastal eutrophication, Science of the total environment. Conf Proc Symp Marine Coastal Eutrophication. Elsevier, Amsterdam, p 785-798

American Bureau of Shipping (1999) Advisory notes on ballast water exchange procedures. Houston, TX

American Public Health Association, American Water Works Association, Water Environment Federation (1998) Standard methods for the examination of water and wastewater, 20th edn. American Public Health Association, Washington, DC

Arar EJ, Collins GB (1992) In vitro determination of chlorophyll $a$ and phaeophytin $a$ in marine and freshwater phytoplankton by fluorescence. Method 445.0. In: Methods for the determination of chemical substances in marine and estuarine environmental samples. Environmental Monitoring Systems Laboratory, Office of Research and Development, US Environmental Protection Agency, Cincinnati, OH 
Ascherson N (1996) Black Sea. Jonathan Cape, London

Ashjian CJ, Smith SL, Lane PVZ (1995) The Northeast Water Polynya during summer 1992: distribution and aspects of secondary production of copepods. J Geophys Res 100: $4371-4388$

Ashjian C, Smith S, Bignami F, Hopkins T, Lane P (1997) Distribution of zooplankton in the Northeast Water Polynya during summer 1992. J Mar Syst 10:279-298

AQIS (Australian Quarantine and Inspection Service) (1993) Shipping ballast water trials on the bulk carrier MV Iron Whyalla. Report No. 2 in Ballast Water Research Series. Canberra, Australia: Rigby G, Steverson I, Hallegraeff G for the AQI Service

AQIS (Australian Quarantine and Inspection Service) (1994) Ballast water ports and shipping study. Report No. 5 in Ballast Water Research Series. Canberra, Australia: Kerr S, for the AQI Service

AQIS (Australian Quarantine and Inspection Service) (1995) Ballast water ports and diseases study. Report No. 7 in Ballast Water Research Series. Canberra, Australia: Herfort A, Kerr S, for the AQI Service

Blanchot J, Chapy L, LeBorgne R (1989) Size composition of particulate organic matter in the lagoon of Tikehau atoll (Tuamoto archipelago). Mar Biol 102:329-339

Cheer S, Gentile JH, Hegre CS (1974) Improved methods for ATP analysis. Anal Biochem 60:102-114

Dorsey TE, McDonald PW, Roels OA (1978) Measurements of phytoplankton-protein content with the heated biuretFolin assay. J Phycol 14:167-171

Flagg CN, Smith SL (1989) On the use of the acoustic Doppler current profiler to measure zooplankton abundance. Deep-Sea Res 36:455-474

Gollasch S, Lenz J, Dammer M, Andres HG (2000) Survival of tropical ballast water organisms during a cruise from the Indian Ocean to the North Sea. J Plankton Res 22:923-937

Hallegraeff GM (1993) A review of harmful algal blooms and their apparent global increase. Phycologica 32:79-99

Harvell CD, Kim K, Burkholder JM, Colwell RR and 9 others (2000) Emerging marine diseases-climate links and anthropogenic factors. Science 285:1505

Hay CH, Tanis D (1998) Mid-ocean ballast water exchange: procedures, effectiveness, and verification. Cawthron Report No. 468, Cawthron Institute, Nelson

Hitchcock GL, Langdon C, Smayda TJ (1987) Short-term changes in the biology of a Gulf Stream warm-core ring: phytoplankton biomass and productivity. Limnol Oceanogr 32:919-928

Holm-Hansen O (1969) Determination of microbial biomass in ocean profiles. Limnol Oceanogr 14:740-747

Holm-Hansen O, Booth CR (1966) The measurement of adenosine triphosphate in the ocean and its ecological significance. Limnol Oceanogr 11:510-519

Karl DM, LaRock PA (1975) Adenosine triphosphate measurement in soil and marine sediments. J Fish Res Board Can 32:599-607

Kelner A (1949) Effect of visible light on the recovery of Streptomyces griseus conidia from ultraviolet irradiation injury. Proc Natl Acad Sci USA 35:73-79

Kuzirian AM, Terry ECS, Bechtel DL, James PL (2001) Hydrogen peroxide: an effective treatment for ballast water. Biol Bull (Woods Hole) 201:297-299

Lawrence CA, Block SS (1968) Disinfection, sterilization and preservation. Lea and Febiger, Philadelphia, PA

Ludin A, Thore A (1975) Comparison of methods for extraction of bacterial adenosine nucleotides determined by firefly assay. Appl Microbiol 30:713-731
Maranda Y, Lacroix G (1983) Temporal variability of zooplankton biomass (ATP content and dry weight) in the St. Lawrence Estuary: advective phenomena during neap tide. Mar Biol 73:247-255

Mills EL, Leach JH, Carlton JT, Secor CL (1993) Exotic species in the Great Lakes: a history of biotic crises and anthropogenic introductions. J Great Lakes Res 19:1-54

Montgomery DC (1997) Design and analysis of experiments, 4 th edn. Wiley, New York

Nalepa TF, Schloesser DW (eds) (1993) Zebra mussels: biology impacts and control. Lewis Publishers, Boca Raton, FL

National Research Council (1996) Stemming the tide. National Academy Press, Washington, DC

Neter J, Kutner MH, Nachtsheim CJ, Wasserman W (1996) Applied linear statistical models, 4th edn. Richard D Irwin, Homewood, IL

Parsons MG, Harkins RW (2000) The Great Lakes ballast technology demonstration project filtration mechanical test program. Mar Technol 37:129-140

Patterson J, Brezonik P, Putman H (1970) Measurement and significance of adenosine triphosphate in activated sludge. Environ Sci Technol 4:569-575

Pisciotta JM, Rath DF, Stanek PA, Flanery DM, Harwood VJ (2002) Marine bacteria cause false-positive results in the Colilert-18 rapid identification test for Escherichia coli in Florida waters. Appl Environ Microbiol 68:539-544

Postel L, Fock H, Hagen W (2000) Biomass and abundance. In: Harris RP, Wiebe PH, Lenz J, Skjoldal HR, Huntley M (eds) ICES zooplankton methodology manual. Academic Press, San Diego, CA

Rigby G, Taylor AH (2001) Ballast water treatment to minimize the risks of introducing nonindigenous marine organisms into Australian ports. Ballast Water Treatment Report No. 13. Dept of Agriculture, Fisheries \& Forestry, Canberra

Ruiz GM, Fofonoff PW, Carlton JT, Wonham MJ, Hines AH (2000a) Invasion of coastal marine communities in North America: apparent patterns, processes, and biases. Annu Rev Ecol Syst 31:481-531

Ruiz GM, Rawlings TK, Dobbs FC, Drake LA, Mullady T, Huq A, Colwell RR (2000b) Global spread of microorganisms by ships. Nature 408:49

Scheible OK, Forndran A, Leo WM (1983) Pilot investigation of ultraviolet wastewater disinfection at the New York City Port Richmond plant. Symp Proc Second National Symposium of Municipal Wastewater Disinfection. EPA/600-9-83-009. Helth Effects Research Lab, Office of Research and Development, US Environmental Protection Agency, Cincinnati, OH

Shapiro SS, Wilk MB (1965) An analysis of variance test for normality (complete samples). Biometrika 52:591-611

Smith RC, Baker KS, Dustan P (1981) Fluorometric techniques for the measurement of oceanic chlorophyll in the support of remote sensing. Scripps Institute of Oceanography, Ref. 81-17, La Jolla, CA

Smith SL, Lane PVZ (1988) Grazing of the spring diatom bloom in the New York Bight by the calanoid copepods Calanus finmarchicus, Metridia lucens and Centropages typicus. Cont Shelf Res 8:485-509

Smith SL, Lane PVZ, Schwarting EM (1985) Zooplankton data report: shelf-edge exchange processes (SEEP) I. Tech Rep No BNL 36260. Brookhaven National Laboratory, Upton, NY

Sutherland TF, Levings CD, Elliott CC, Hesse WW (2001) Effect of a ballast water treatment system on survivorship of natural populations of marine plankton. Mar Ecol Prog Ser 210:139-148

Tamburri MN, Wasson K, Matsuda M (2002) Ballast water deoxygenation can prevent aquatic introductions while reducing ship corrosion. Biol Conserv 103:331-341

Submitted: May 22, 2002; Accepted: May 6, 2003

Proofs received from author(s): August 13, 2003 